\title{
Environmental Conflict Is Mediation the Answer?
}

\section{John Deaton}

\begin{abstract}
In this article I discuss the opportunities for mediation and neutral facilitation in the Irish town planning and environmental systems. I examine the shortcomings of the existing system. I show how the system inhibits the settling of disputes by consent. I examine the public consultation process and the opportunities for the mediator in facilitating a fairer outcome. I make reference to the planning system of other countries where mediation has been introduced. I draw on the studies and reports which have been prepared by our nearest neighbour the U.K. I make suggestions for changing the system and tell how C.I.Arb. is actively engaged in the development and promotion of mediation in the Irish planning and environmental systems.
\end{abstract}

\section{Keywords}

Environmental conflict, mediation

\section{Introduction}

In this article I explore and discuss the opportunities for the use of mediation and neutral facilitation as a means of both dispute avoidance and dispute resolution in the Irish town planning and environmental sectors. To do this, I will describe the Irish Town planning system and explore whether mediation and neutral facilitation are possible or desirable and whether regulations and practice should be changed to accommodate these practices. In addition, I will outline the work in which C.I.Arb. Ireland is engaged to develop and promote mediation in the Irish planning process.

I was drawn to this subject firstly by my own experience in running an architectural practice for over 25 years and latterly my work in alternative dispute resolution. Based on this knowledge and experience I have concluded that the system of dispute avoidance and resolution within the Irish Planning system is in need of improvement, to say the least.

On researching the subject, I found that planning related mediation was already well established in a number of countries, in particular Australia and New Zealand, whilst in the U.K it had been examined at Government level leading to the introduction of mediation into the planning system. 
At an Away-Day run by The Chartered Institute of Architects Ireland in 2012 I presented the results of my research and suggested that a special interest group be set up to develop and promote planning and environmental mediation in Ireland. This suggestion was enthusiastically received, following which I was appointed chairman of the group.

After two years of work by the group the Irish Branch of C.I.Arb now has a panel of specially trained and accredited members who have begun to engage in planning and environmental mediation. The type of mediations undertaken so far include:

- A planning dispute between neighbours in which the planning authority was also involved;

- A dispute regarding the provision of site services between developers of adjoining lands; and

- A planning dispute between adjoining neighbours where a dispute over land ownership was at the core.

All of these disputes have been settled.

The panel has recently completed a major review and report on the public consultation process used by one of Ireland's largest utility companies - Eirgrid.

\section{Why is dispute endemic in the planning process?}

We can look no further than a definition to understand why Planning and Environment is prone to dispute. According to Taylor (2007) the planning process is ".............to guide and ensure the orderly development of settlements and communities." Thus we can see how issues can arise: guiding and ensuring raises issues of control and compliance. These issues may be complicated where one group has greater power and resources and other groups or individuals have little or none.

Orderly development implies that there should be a consensus with respect to principles and objectives which in reality may be difficult to achieve where there are different social and cultural groups within society who may not share the same values.

Intrinsic in planning disputes is that there is a party who initiates the proposal (a private developer, a public utility, a local authority) and the one who is affected by the proposal (the private citizen, company, community). "Proposal" means, not just a planning application, but all environmental plans which affect others (e.g. development plans, local area plans, public utilities, public events). Opinions and attitudes can be starkly different between proposer and those affected by the proposal.

In this context the potential for environmental disputes is quite significant, and in fact disputes are an everyday occurrence in modern society. Indeed, at present Ireland seems to be racked with such disputes.

\section{The Range of Planning Disputes}

The size and nature of disputes can vary from the "mega-development" dispute to the small scale neighbour dispute.

Large infrastructural projects include: wind energy, electricity transmission and gas exploration. Two particularly high profile disputes are: 
- Corrib Gas Field: In 2005 Enterprise Oil sought to build a refinery to exploit an off-shore oil field of one trillion cubic metres of natural gas. In the face of intensive local opposition, planning appeals, protest and legal actions no gas has yet come been brought to shore.

- Eirgrid: The plans for fulfilling a mandate from Government in respect of electricity transmission to upgrade the National Grid and North-South Interconnector have been greeted with outrage and protest in respect of both the design of the system and perceived shortcomings in the consultation process.

In the context of the need to change our energy consumption and production to take account of climate change, society has an interest in resolving energy disputes in a timely and efficient manner. Historically public utility companies had been given considerable autonomy in how they plan their networks. They were also given the power to compulsorily acquire lands. The individual who sought to challenge a public utility scheme was faced with confronting an entity which had vastly superior financial and technical resources in a context where legislation was supportive of that utility. Compliance with European Law and Directives has brought a change to this situation. Public utilities are no longer exempt from the need to obtain planning permission, for example. The rights of the individual have been substantially expanded and the public is more aware of those rights. The internet has become a forum for sharing of information and comments and for organising protest. Ireland's post-colonial culture of grudging acceptance of public administration and the law is changing. We now have a well-educated and organised community which rightly seeks to be engaged and consulted in respect of any decision which affects it. Taking this into account a consensual resolution of disputes is clearly called for.

On a different scale we see the domestic planning dispute. This type of dispute, although appearing small, can be more personally damaging than the big protest issues. Frequently we see neighbour disputes over planning applications or infringements. These often involve long drawn-out expensive legal proceedings which result in personal stress and often permanent estrangement between neighbours. I recently mediated a dispute between neighbours where one neighbour had not complied with the terms of his planning permission and had destroyed the tree-lined boundary to his neighbour's lands. The dispute was three years old and had drawn the threat of enforcement from the planning authority. Both parties were traumatised by the dispute. High Court action was imminent. The mediation settled on the day and was sealed with a handshake and a promise of future neighbourly co-operation.

\section{Mediation}

The Scottish Executive, Development Department (2007) defines mediation as being: "a process involving an independent third party whose role is to help parties to identify the real issues between them, their concerns and needs, the options for resolving matters and, where possible, a solution which is acceptable to all concerned."

As mediators we know the advantages of the process:

- Effective - the majority of mediations produce an agreed settlement.

- Enduring - participants tend to honour the agreements reached at mediation. 
- Engagement - the participants have the opportunity to engage directly in a neutral forum.

- Equality of expression - properly designed and mediated, the process can mitigate imbalances of power and resources.

\section{The Irish Town Planning System - Does it need to change?}

Irish town planning law and administration has many worthy features:

- Openness - that the system be open to all. The rights of "third parties" are rightfully enshrined in the Irish system.

- Transparency - that all parties have the right to information related to the making of policy and decisions.

- Consultation - that all parties have the right to be consulted in respect of public policy and projects.

- The right to appeal is available at all steps in the planning process including the right to judicial review by the Courts.

\section{PLANNING POLICY}

Planning policy for an area is governed by a five-year Development Plan. A Draft Development Plan is firstly prepared. This is advertised for public submissions to be taken into account on the basis upon which the Development Plan is made and adopted. Planning authorities may request public submissions to inform the preparation of the Draft Development Plan. However, private landowners are prohibited from making submissions at pre-draft stage. Only submissions dealing with general planning matters are allowed to be considered. Thus the landowner may only make representations after the Draft Development Plan has been made. In effect, the planning authority has made its plan (the Draft Development Plan) to which it cannot but be committed. The landowner seeking to make his views known is in effect an "objector" to the Planning Authority's own plan. This is an inherent defect in the system which understandably produces conflict. A consultation process involving a neutral third party could facilitate a fairer and more meaningful engagement between the maker of the Draft Plan and the person(s) affected by it. This would require both a change in policy and an openness to a facilitated dialogue.

\section{PLANNING CONTROL}

All decisions on planning applications must comply with the Development Plan. Section 247 of the Planning and Development Act 2000 contains the provision that a party wishing to make a planning application can be provided a pre-planning consultation with the planning department. It is important to note that such consultations are not to be taken as negotiations but are limited to the giving of advice to prospective applicants. Third parties who might be affected by the application are excluded from the process. 
When a planning application is made there is a strict eight-week time limit for rendering a decision. Third parties can submit "observations" within a strict 5-week period. In effect these observations are generally objections seeking the refusal of permission or modification of the plans. The applicant may have an interest in addressing these observations by meeting with the observer and agreeing changes. However, should the applicant meet with the observer and agree to revise the plans there is no provision for him to submit them to the planning authority because "unsolicited additional information" will not be accepted. Also, there are only three weeks from the close of the third-party submissions process to the issuing of the planning decision which is often too short a time for negotiation. In effect, the applicant and a third party objector have neither the time nor the space to resolve any differences between them and are on a collision course to the planning appeal process which will inevitably begin when the planning decision has been made. Thus, the opportunity for mediation at a most critical time is not currently available. The process as currently structured would seem to exacerbate if not create conflict. There may well be the prospect of agreement in substance between the parties (including the planners) but the current system precludes them from exploring common ground or reaching an agreement which would be in the best interests of all. This needs to change.

In the Irish system the planning authority can only "stop the clock" by issuing a request for additional information. Presently, the planning authority only uses the request for additional information system to seek clarification or to seek an amendment to the submitted plans. The applicant is given 6 months to submit the additional information. It would surely be possible to devise a system where the planning authority, under the request for information process, could suggest to the parties that they consider mediation. This would allow the parties the time and space for mediation. Any agreement reached as a result of the mediation between the parties could be submitted as additional information for the consideration of but not binding upon the planning authority.

\section{PLANNING APPEALS}

An Bórd Pleanála (Planning Board) is the "court of appeal" against the decisions of the planning authority. Initially conceived as a board comprised of both planners and "laymen" the Board has been given increasing responsibilities and powers as planning law has been developed. Whilst it cannot make policy it is in effect the final authority on planning matters aside from the courts. Because it is charged with resolving appeals it has a duty to act judicially; it must follow established procedures and make decisions based on the facts and the law. A decision by the Board can be the subject of judicial review by the Court. Thus the Board must insure that it has acted in a transparent and judicial manner in coming to its decision. The decision is non-consensual, yet is binding. It is in effect a form of arbitration —with its usual disadvantages of expense, delay and where the parties are not in control of the outcome.

Early on in my architectural practice a client would often ask that I seek an oral hearing for his planning appeal. His intention was that he would have the opportunity of explaining his case to a neutral person. Today, oral hearings are very different from this naive expectation. They imitate court hearings 
complete with the giving of evidence, expert opinions, legal counsel, and the other elements and trappings of a judicial process. They are essentially adversarial and can be intimidating for the lay participant. They are very expensive and largely outside the reach of the private individual.

There is a strict time limit for filing written appeals and responses by the parties. Once a party submits an appeal he is not allowed to further correspond unless requested by the Board. The same applies to a responding party. Thus, there is no effective forum for discussion or negotiation between the parties to an appeal (an applicant and a third-party appellant for instance). This deprives the parties of an opportunity to reach a compromise. Often the decision of the Board when it is finally made may not suit either of the parties! Can we not have a provision similar to what can occur in civil litigation whereby the parties would be free to communicate, negotiate and ultimately resolve their differences and then present an agreed joint position document to the Board? The Board of course would notbe obliged to accept parties' agreement but it is difficult to see how it would not be persuasive in the making of the Board's decision. The Board would remain free to consider public policy or the submissions of other parties to the appeal.

\section{"STOPPING THE CLOCK"}

Of the shortcomings in the planning process and the opportunities for mediation that I mention above a common thread is the need to make provision for "stopping the clock". British experience supports this view. Roeze (2010) in a report commissioned by the National Planning Forum and Planning Inspectorate in the U. K states that the results of fourteen interviews with key players in the planning system included amongst its findings that ".......essons can be learned from mediation processes in other areas of law, where mediation is the default process and it can be decided to "stop the clock" by having an adjournment."

\section{PLANNING SCHEMES}

Quite aside from planning applications there are many other areas where mediation would help to avoid or resolve disputes. For example:

- Schemes made under Part 8 of the Planning and Development Act (2000) where the local authority grants planning permission to itself for its own scheme having "considered" the observations of the public or affected third parties. This is done by written submission and there is no forum for the observer to negotiate and resolve differences with the local authority. Mediation would provide such a forum.

- In Local area plans and Area action plans, mediation would provide a forum for negotiation and agreement.

- Strategic infrastructural projects exempt from the need to obtain planning permission. A properly structured public consultation process (by a third party neutral with mediation skills) would afford the parties an opportunity to understand each other's position and to design an agreed scheme and to make arrangements for future co-operation and engagement during the implementation phase.

- Event licenses: The recent cancellation of the Garth Brooks concerts in Dublin is a graphic example of 
the need for early mediation. In this case a "mediation" took place after an irrevocable decision was made by the local authority.

- Planning enforcement disputes where mediation could be attempted as alternative to litigation.

- Disputes regarding the taking in charge of the roads and services completed as part of a housing development. There are many competinginterests:

planners, roads engineers, developer, local residents. Mediation is the best forum to bring them together.

\section{PUBLIC CONSULTATION}

In recent times we have seen considerable progress in the promotion and development of the concept of public consultation. In June 2012 Ireland ratified the Aarhus Convention which includes public participation in decision-making.

I suggest that Irish Planning should follow the principles of consultation as set out by Hodgson in a British Court case, R v Brent London Borough Council (1985), and known as the Gunning Principles:

- Consultation must take place when the proposal is still at a formativestage;

- Sufficient reasons must be put forward for the proposal to allow for intelligent consideration and response;

- Adequate time must be given for consideration and response; and

- The product of consultation must be conscientiously taken intoaccount.

Public consultation is now recognised as an essential where large scale works are proposed which affect large numbers of people. These works are often proposed by public bodies or corporations (such as planning authorities, roads authorities, public utility corporations, public/private partnerships etc.) who have extensive financial, technical and administrative resources capable of overwhelming the planning process. Compare their resources to the resources of those whose lives and property may be affected by the proposal and who may have scarce financial or technical resources and very little influence at high levels of administration. The lack of proper public consultation can produce suspicion, disengagement, conflict, outrage and protest. This can leave broken lives and disaffected communities in its wake.

There has been much public criticism of public consultation in Ireland on the basis that it was limited to the dissemination of information and that the canvassing of submissions was little more than tokenism with no real prospect of the proposal being changed in any meaningful way. This points to the need for a "third-party neutral" involvement to:

- Assist all parties in the design the consultation process.

- Facilitate the consultation in a neutral fashion, attending to any power imbalances.

- If required, deliver an unbiased report on stakeholder feedback.

The third- party neutral in this case would be a mediator but with additional training and experience in the skills of public consultation. 
Essential to the process will be a commitment to follow the Aarhus and Gunning principles in that the consultation can effect a change to the original proposal, including the "zero option". The mediator would ensure that the parties in designing the consultation process make this commitment. The mediator will be charged with the responsibility of reporting fairly on the feedback from both parties which is then published in an agreed forum. This would help to ensure that the proposing party cannot disregard the consultees' feedback.

\section{Benefits of Environmental Mediation}

The benefits of mediation would include that:

- It fosters meaningful engagement between the parties.

- The dispute can be reduced to its core issues.

- Most importantly revised plans and arrangements can be agreed with the possibility of more creative solutions emerging.

- Participants can agree options and strategies for resolving current and future disputes.

- They can agree the process and protocol for implementation of the development and continued cooperation between the parties.

Society would benefit from having a means of resolving disputes through mediation by reducing the number of appeals and the time and cost of reaching decisions.

Research on the potential of mediation to reduce appeals and to effect savings was undertaken by Wellbank (2000 \& 2002) who looked at the New Zealand Environment Court which uses mediation. Wellbank found that appeals were avoided in $75 \%$ of mediated cases resulting in very significant savings in time and cost.

\section{Mediation is not a Panacea}

It would be a mistake to assume that Mediation is a panacea for all planning ills. It is not appropriate to every dispute, for instance where deliberate law breaking or criminality is involved, or where granting the requested permission would be prohibited by law (such as making a material contravention of the development plan). Rather it is for use alongside the other dispute resolution methods within the planning system. Nonetheless, mediation has been shown to be applicable to a wide range of environmental disputes.

Core Solutions Group in association with Scottish Government in its "Guide to the Use of Mediation in the Planning System in Scotland" (2009) provides examples of how mediation has been successfully employed on a range of planning issues from simple planning applications to large scale community conflicts in Australia, USA, South Africa, Scotland and England. 


\section{Limitations}

In promoting mediation either by way of working within or changing the system we must be mindful of principles which on the face of it would appear to be conflicting. For instance, we need to balance the need for confidentiality within the mediation process with the requirement that the planning system must be open and transparent. I see no issue with an applicant for permission and a third- party objector having a private and confidential mediation where the results of that mediation (the agreed position) are then offered into the public forum (the planning process) as non-binding for consideration. The right of third party appeal is particularly protected in the Irish system (as compared to our neighbours in the U.K.). This means that the planning process must at all times be open to third party scrutiny. It is difficult to see how any mediation could be (or indeed should be) private and confidential where a planning officer or public official takes part.

Mediation is not a surrogate planning process. Environmental Mediation agreements would not be private. Non-participating parties will still have the right to opt out of the mediation process but the planning authority is still legally bound to consider their views. The County Manager or An Bórd Pleanála will still make the final decision, taking public policy and the views of all partiesinto account.

If we can fashion a participative system that will foster trust and reduce the delay and costs associated with the current restrictive confrontational model, the economy and society in general would benefit.

\section{Who pays?}

A frequently asked question is "Who pays the mediator?" More importantly, "Who initiates mediation?"

The answer will depend on the circumstances, for example:

- In a private neighbour dispute the parties may agree to share the cost.

- Where one party has more resources it may propose to pay most or all of the cost e.g. a developer in mediation with a homeowner or community group.

- Where there is a public undertaking it may be in the public interest that the public body would bear the cost.

In New Zealand a free mediation service is provided by the planning authority. Whilst this is unlikely to be the case in Ireland it does not mean that local authorities would never consider financing a mediation. There may well be cases where the planning authority would consider it more economically prudent to engage in mediation as an alternative to litigation, for example: planning enforcement and taking-in-charge disputes.

It is important that the neutrality of the mediator is not perceived to be compromised by one party bearing the costs of the mediation. This can be achieved in two ways:

- Give all the parties a say in the choice of mediator and in the event of disagreement the mediator would be nominated by an independent body. 
- Engage the parties in pre-mediation and give them an opportunity to contribute to the design the mediation process. This will enhance the parties feeling of ownership of the mediation process and will encourage trust.

\section{The prospects for Mediation in Ireland}

In a Report from the Law Reform Commission, "Alternative Dispute Resolution; Mediation and Conciliation" (2010), mediation was considered with a view to its role in the resolution of planning application disputes. In concluding its consideration of the matter, the Commission recommended that "local planning authorities should consider whether a more formal approach to resolving issues in the planning process such as the introduction of a mediation scheme is appropriate".

Mediation is now provided for in the Rules of the Superior Courts and is increasingly being promoted by Government and the European Union as a first resort in terms of the resolution of disputes. The Mediation Bill 2012 published by Government deals with codifying and regulating mediation in Ireland. It is hoped that this Bill will be passed into law in 2015.

In promoting environmental mediation, we can point to other countries which provide a template for a new system together with a base of experience from which to learn.

Mediation was adopted by statute into the Australian town planning appeal system in 1994. Their planning system shares many characteristics with Irish and British systems. In the Australian system there are two types of mediation provided:

- In-house mediation for disputes before and during the planning application and

- Mediation for appeals of decisions.

We can learn from the promotion and development of environmental mediation by our nearest neighbours Britain and Scotland.

\section{C.I. Arb. - Planning and Environmental Mediation Project}

We in Chartered Institute of Arbitrators Irish Branch have charged ourselves with lobbying for the introduction of mediation into the existing planning system. We see this as supporting the development of the environment. We seek to make the existing planning system more efficient and effective and to encourage public participation based on trust. Through our base at the Dublin Dispute Resolution Centre we offer a mediation and facilitation service through our panel:

- 20 mediators, all of whom have complementary qualifications in the planning, environmental and legal disciplines.

- All mediators have successfully completed specialised training in environmental mediation.

- We operate a Code of Conduct and Complaints Procedure.

- We engage in Continuing Professional development and Learning and Sharing groups. 
Since the formation of the panel our members have been engaged on a number of appointments ranging from a planning enforcement/neighbour dispute to a large scale public consultation study. Our immediate objective is to build up a stock of case studies (some of which I have mentioned in this article). We will use these case studies to show to the public and to Government the very real advantages of mediation in the Irish Town Planning and Environmental systems. 


\section{References}

Core Solutions Group in association with Scottish Government (2009) A Guide to the Use of Mediation in the Planning System in Scotland, ISBN 9780755974498 (Web only publication)

Hodgson, Mr Justice in R v. Brent London Borough Council, ex parte Gunning (1985) 84 LGR 168 at 169

Law Reform Commission (2010) Report on Alternative Dispute Resolution: Mediation and Conciliation, ISSN 1393-3132

Planning and Development Act 2000 - Irish Statute Book No. 30 of 2000

Scottish Executive, Development Department (2007) Community Engagement - Planning with People PAN 81, RR Donnelly B4711203/07

Taylor, Nigel, (2007). Urban Planning Theory since 1945, London, Sage.

Welbank, M. in association with Davies, N. and Haywood, I. (2000) Mediation in Planning.

Department of the Environment, Transport and the Regions, London.

Welbank, M., Davies, N., Haywood, I., Shenfield, M. and Ayvazyam, T. in association with Grant, M. and Dean, J. (2002) Further Research into Mediation in the Planning System.

Planning Research, Office of the Deputy Prime Minister, London.

\section{Further reading}

National Planning Forum (2011), Mediation in Planning - A Short Guide, U.K. http://www.natplanforum.org.uk/110407\%20Mediation\%20short\%20guide_final.pdf Rozee L. OBE, Powell K (2010) Mediation in Planning - Report commissioned by the National Planning Forum and the Planning Inspectorate, UK http://www.natplanforum.org.uk/Final\%20Report\%20$\% 20$ Mediation $\% 20$ in $\% 20$ Planning $\% 20$ -

\%20PDF.pdf

Stubbs M (1996) The Cutting Edge: New approaches to mediation in town planning disputes. Oxford Brookes University ISBN 0-85406-930-5

John Deaton is an accredited mediator and founding chairman of the Planning and Environmental Mediation group in the Chartered Institute of Arbitrators - Irish Branch. He is an architect in private practice - director of Deaton Lysaght Architects, founded 1990. An accredited arbitrator since 1999, he is committed to practising and promoting Alternative Dispute Resolution such as mediation and conciliation. He has a particular interest and expertise in environmental dispute resolution and public consultation. 